\title{
Symptomatic nucleus of homeopathic remedies: remedies derived from carbon as case-study.
}

\author{
Luciana Costa Lima Thomaz
}

Associação Paulista de Homeopatia, SP, Brazil

\begin{abstract}
Homeopathic clinical practice requires both accuracy and agility in diagnosis and prescription of treatment during real-time consultations. Several approaches have been attempted to facilitate this process including different criteria to group homeopathic remedies. This study sought to establish whether classification according to the chemical composition of substances used as basis of homeopathic remedies have correspondence in the experimental homeopathic materia medica. Methods: The homeopathic remedies derived from carbon were selected as case-study. The experimental symptoms of these remedies were compared and a nucleus of symptoms common to all could be found. This nucleus was then compared to similarly obtained nuclei of experimental symptoms of homeopathic remedies derived from sulfur and phosphor to test qualitative specificity and finally to the traditionally described clinical picture of the so-called homeopathic carbonic constitution to establish whether the latter has homeopathic experimental grounds. Results: a nucleus of experimental symptoms common to homeopathic remedies derived from carbon was found, qualitatively different from the symptomatic nuclei of homeopathic remedies derived from sulfur and phosphor; no correlation was found, however, with the clinical image of so-called carbonic constitution.
\end{abstract}

Keywords: Homeopathy; Materia Medica; Remedies; Classes; Carbon

\section{Introduction}

The homeopathic materia medica, namely, the compilation of homeopathic remedies and their effects on human beings is extremely large. For this reason, some methods and techniques have been suggested to facilitate the study of remedies as well as their selection in real-time consultations. The best known among them is known as "repertory" and consists in the reverse of the materia medica: symptoms are listed as in a dictionary according to topographical and alphabetical criteria, together with their corresponding remedies.

Another possibility is to resort to classifications of remedies. In this context, several authors have suggested different criteria to systematize the homeopathic materia medica. It can be said that the first to attempt this approach was Samuel Hahnemann, the founder of Homeopathy, who classified and listed remedies as "apsoric", "antipsoric", "antisycotic" and "antisyphilitic" [1]. This same approach was kept by later authors, as e.g. N. Ghatak [2].
Still other authors appealed to eclectic and singular approaches. For instance, Alfonso MasiElizalde essayed a systematization of remedies according to Aquinas' description of Divine attributes, as represented in the latter's Summa Theologica [3].

More recently, Rajan Sankaran typified remedies according to the properties of the three kingdoms of nature, viz. mineral (presenting chiefly disturbs of structure), vegetal (the accent falls on sensitiveness) and animal (survival, as main issue), as deriving from the periodic table of elements, botanical taxonomy, etc [4]. A similar approach, also emphasizing taxonomies has been suggested by Jan Scholten [5]. Both had a less known antecedent in the work of Otto Leeser, in the 1930s, who also employed the periodic table of elements as the basis for a study on salts grounded on experimental biochemistry [6].

In this context, mineral remedies have received particular attention, and classifications grounded on their chemical composition and possible physiological actions have been attempted since the $19^{\text {th }}$ century, as e.g. in the works of E. von 
Grauvogl and W.H. Schlüssler [7,8]. Inspired by these ideas, in the following century, Swiss homeopath Antoine Nebel correlated biochemical notions to endocrine functions, formulating in this way the notion of "homeopathic constitutions". Léon Vannier continued the studies on such "constitutions", while emphasizing the osteomuscular structure of individuals, whereas Henri Bernard classified remedies and constitutions according to their correlation to the embryological layers and the biochemical structure of mineral remedies derived from salts [9-11].

An heir of this tradition, Roland Zissu, nevertheless, warns that correlations between homeopathic remedies derived from mineral salts and human constitutions can be confusing, as attempts to classify human types according to morphological, physiological and mental data have no direct relationship to either the principles of Homeopathy or the homeopathic remedies hypothetically related to such constitutions [12].

More recently, Bungetzianu and Jurj [13-15] introduced an approach to the study of the materia medica aiming at integrating homeopathic experimental data, on the one hand, and physiological and clinical information, on the other, by verifying whether there was correlation between the chemical composition of substances used as basis of homeopathic remedies and the corresponding homeopathic remedies, bridging in this way the gap between general medical and homeopathic knowledge.

Our study aimed to verify if there actually are symptomatic nuclei common to families or classes of homeopathic remedies as described in the experimental homeopathic materia medica, i.e. product of homeopathic pathogenetic trials, toxicological and clinical reports. On the one hand, this study would help to verify whether or not symptomatic nuclei can be related to biochemical, botanical, and other taxonomies or refute them. On the other, a positive result can contribute to clinical practice, by introducing delimitations in the field of pharmacological options, which would facilitate the selection of remedies in real-time consultations.

The present article presents the study of one class of homeopathic remedies, namely those derived from carbon compounds, designed to establish the possible existence of a symptomatic nucleus common to all of them.

\section{Materials and Methods}

The first step of this research sought to identify all remedies derived from carbon. To fulfill this goal, digital repertory Synthesis 9 was used [16]. From this initial list of remedies, according to the purpose of this study, we selected those remedies which may be rated as the most representative, due to the number of corresponding symptoms. Inclusion of so-called "small remedies" - which present a small number of symptoms since they have not been sufficiently proved - would hinder on methodological grounds the identification of a possible common symptomatic nucleus of homeopathic remedies derived from carbon.

The next step was to perform a comparative extraction of the selected remedies, identifying in this ways all the symptoms common to all of them. As the outcome was positive and eighty symptoms were identified, we proceeded to an analysis of these symptoms in order to define the symptomatic nucleus common to homeopathic remedies derived from carbon.

To test the consistency of the symptomatic nucleus thus established, we performed a similar study with homeopathic remedies derived from sulfur and phosphor [16]. This is to say, we hypothesized that the symptomatic nucleus identified for homeopathic remedies derived from carbon might not be specific for that class if it were composed by exceedingly general symptoms, common to many other homeopathic remedies not derived from carbon. Comparison of the possible nucleus of homeopathic remedies derived from carbon to the possible symptomatic nuclei of homeopathic remedies derived from two major sources, namely phosphor and sulfur, would help to settle this issue.

Finally, we compared our results with homeopathic remedies derived from carbon obtained by analysis of the experimental homeopathic materia medica - and traditional notions on so-called "carbonic constitution" together with the homeopathic remedies that hypothetically would represent them in order to establish whether they have some empirical foundation or are result of pure speculation. Sources employed were Bernard and Franco $[10,11,17]$, as the former represents the traditional view on so-called homeopathic constitutions and the latter presents a comprehensive review and systematization of this notion.

\section{Results}

\section{Remedies derived from carbon in the homeopathic materia medica}

Remedies derived from carbon listed in the experimental homeopathic materia medica are described in Table 1.

Table 1. Remedies derived from carbon in the Materia Medica 


\begin{tabular}{|l|l|}
\hline Remedy & Composition \\
\hline Adamas & Pure mineral carbon (diamond) \\
\hline Ammonium carbonicum & Ammonium carbonate \\
\hline Baryta carbonica & Barium carbonate \\
\hline Calcarea carbonica & Calcium carbonate (oyster) \\
\hline Cuprum carbonicum & Copper carbonate \\
\hline Ferrum carbonicum & Iron carbonate \\
\hline Graphites & Mineral carbon slightly mixed with iron \\
\hline Kalium carbonicum & Potassium carbonate \\
\hline Magnesium carbonicum & Magnesium carbonate \\
\hline Natrum carbonicum & Sodium carbonate \\
\hline Strontium carbonicum & Strontium carbonate \\
\hline Zincum carbonicum & Zincum carbonate \\
\hline Carboneum & Amorphous carbon \\
\hline Carboneum chloratum & Carbon tetrachloride \\
\hline Carboneum hydrogenisatum & Hydrogenated carbon \\
\hline Carboneum oxygenisatum & Carbon monoxide \\
\hline Carboneum sulphuratum & Carbon bisulphate \\
\hline & \\
\hline
\end{tabular}

For comparison purposes, homeopathic remedies Carbo vegetabilis and Carbo animalis were excluded, as their sources are extremely complex organic materials. On the other hand, homeopathic remedies Graphites and Adamas were included in the comparison as they derive from native form of carbon. As it was stated above, minor salts were excluded, as also Carboneum sulphuratum, since its chemical composition (carbon and sulfur) intersects two main classes to be compared in this study (homeopathic remedies derived from carbon and sulfur).

Remedies which thus fulfilled inclusion criteria were: Adamas, Ammonium carbonicum (Am-c), Baryta carbonica (Bar-c), Calcarea carbonica (Calc), Graphites (Graph), Kalium carbonicum (Kali-c), Magnesium carbonicum (Mag-c) and Natrum carbonicum (Nat-c). Symptoms common to all were extracted with the help of software Radar Brasil 9.2.1, results are presented in Table 2.

Table 2. Symptoms common to homeopathic remedies derived from carbon

\begin{tabular}{|l|}
\hline Total \\
\hline MIND - ABSENTMINDED \\
MIND - ANGER \\
MIND - ANXIETY \\
MIND - CONCENTRATION - difficult \\
MIND - CONFUSION of mind \\
MIND - DULLNESS \\
MIND - FORGETFUL \\
MIND - INDIFFERENCE \\
MIND - IRRITABILITY \\
MIND - LAZINESS \\
MIND - MEMORY - weakness of memory \\
MIND - MENTAL EXERTION - aversion to \\
MIND - MOROSE \\
MIND - PROSTRATION of mind \\
MIND - QUARRELSOME \\
MIND - SADNESS \\
MIND - SENSITIVE - noise, to \\
MIND - TACITURN \\
MIND - TIMIDITY \\
VERTIGO - VERTIGO \\
HEAD - HEAVINESS \\
HEAD - PAIN - Forehead \\
EYE - PAIN
\end{tabular}

80
CHEST - PALPITATION of heart
BACK - PAIN
EXTREMITIES - HEAVINESS
SLEEP - SLEEPINESS
SLEEP - WAKING - fright, as from
DREAMS - AMOROUS
DREAMS - ANXIOUS
DREAMS - VIVID
CHILL - CHILL in general
CHILL - INTERNAL
CHILL - SHAKING
SKIN - BURNING - scratching; after
SKIN - ITCHING
SKIN - ITCHING - burning
GENERALS - SIDE - right
GENERALS - SIDE - left
GENERALS - AIR; IN OPEN - amel.
GENERALS - AIR; OPEN - desire for open air
GENERALS - COLD - air - agg.
GENERALS - COUGH - during - agg.
GENERALS - DRYNESS of usually moist
internal parts
GENERALS - EXERTION; physical - agg.




EAR - NOISES in
NOSE - CORYZA - cough - with
NOSE - SMELL - acute
FACE - DISCOLORATION - pale
MOUTH -
DISCOLORATION -Tongue - white
MOUTH - DRYNESS
MOUTH - SALIVATION - profuse
THROAT - LUMP; sensation of a
THROAT - PAIN - sore
STOMACH - APPETITE - increased
STOMACH - THIRST
RECTUM - CONSTIPATION - difficult stool
STOOL - HARD
URETHRA - PAIN - urination - during
- agg. - burning
COUGH - LOOSE
EXPECTORATION - YELLOW
CHEST - OPPRESSION

Analysis of these 80 symptoms allowed us to identify a symptomatic nucleus common to homeopathic remedies derived from carbon, which is described as follows:

- On the mental level: distraction, difficulty to concentrate, weak memory, lack of motivation, apathy and indifference, with mental prostration and moroseness; aversion to mental effort and lassitude. Humor can be variable and changing, with an inclination for quarreling, sadness and timidity.

- Head: feeling of a weight, especially on the forehead.

- Eyes: pain.

- Ear: tinnitus.

- Nose: coryza with cough; sensitiveness to odors.

- Face: paleness.

- Mouth: dryness; paleness of the tongue; copious salivation.

- Throat: feeling of a lump.

- Chest: loose cough; yellowish expectoration; feeling of oppression; palpitations.

- Abdomen: increased appetite and thirst; constipation; hard stools.

- Genitals: increased sexual desire (women)

- Urinary: pain in the urethra during micturition

- Locomotor system: backache; heaviness of the limbs.

- Sleep: sleepiness; fright on waking.

- Dreams: amorous; anxious; vivid.
GENERALS - HEAT - flushes of

GENERALS - HEAT - lack of vital heat

GENERALS - HEAT - sensation of

GENERALS - HEAVINESS - Externally

GENERALS - HEAVINESS - Internally

GENERALS - LASSITUDE

GENERALS - LYING - amel.

GENERALS - MOTION - agg.

GENERALS - OBESITY

GENERALS - PAIN - pinching pain

GENERALS - PAIN - sore

GENERALS - PAIN - Internally - pressing pain

GENERALS - PERIODICITY

GENERALS - SWELLING - general; in

GENERALS - WAKING - on

GENERALS - WEAKNESS

GENERALS - WEAKNESS - walking - agg.

GENERALS - WEARINESS
- Chills: chills and trembling by cold; internal trembling.

- Skin: burning itch.

- Temperature: desire for and amelioration by fresh air; aggravation by cold air; flushes of heat; lack of vital heat; feeling of heat.

- Modalities of aggravation: by cough; by physical effort; motion; upon waking up.

- Modalities of amelioration: lying down

- Sensations: of internal and external heaviness; lassitude; internal pressing pains; pains as by a wound; pain with feeling of tightness.

- Generals: obesity; periodicity of symptoms; swellings; weakness, especially when walking; exhaustion.

\section{Remedies derived from sulfur and phosphor in the homeopathic materia medica}

By the same criteria, remedies derived from sulfur and phosphor were selected and symptoms common to all in the respective class were extracted. For the sulfur class, remedies selected were: Calcarea sulphurica, Hepar sulphur, Kalium sulphuricum, Magnesium sulphuricum, Natrum sulphuricum, Sulphur and Sulphuricum acidum; for the phosphor class: Calcarea phosphorica; Kalium phosphoricum; Magnesium phosphoricum; Natrum phosphoricum; Phosphoricum acidum and Phosphorus. Results are described in Tables 3 and 4. Symptomatic nuclei of homeopathic remedies derived from sulfur and phosphor were also identified; comparison to the symptomatic nucleus of homeopathic derived from carbon is described in Table 5.

Table 3. Symptoms common to homeopathic remedies derived from sulfur 


\begin{tabular}{|c|c|}
\hline Total & 100 \\
\hline MIND - AILMENTS FROM - mental exertion & BLADDER - URINATION - frequent \\
\hline MIND - DISCONTENTED & BLADDER - URINATION - frequent - night \\
\hline MIND - DULLNESS & BLADDER - URINATION - involuntary \\
\hline MIND - EXCITEMENT & URINE - COPIOUS \\
\hline MIND - IRRITABILITY & MALE GENITALIA/ SEX - POLLUTIONS \\
\hline MIND - LAZYNESS & FEMALE GENITALIA/SEX - MENSES - \\
\hline MIND - MENTAL EXERTION - agg & frequent; too \\
\hline MIND - MENTAL EXERTION - aversion to & FEMALE GENITALIA/SEX - MENSES - painful \\
\hline MIND - SADNESS & FEMALE GENITALIA/SEX - SEXUAL DESIRE - \\
\hline MIND - SENSITIVE & increased \\
\hline MIND WEEPING & LARYNX AND TRACHEA - VOICE - hoarseness \\
\hline VERTIGO - WALKING - agg & COUGH - DRY \\
\hline HEAD - CONGESTION & COUGH - TICKLING \\
\hline HEAD - MENTAL EXERTION - agg & CHEST - CONSTRICTION \\
\hline HEAD - PAIN & CHEST - PAIN \\
\hline HEAD - PAIN- mental exertion & BACK - PAIN - lumbar region \\
\hline HEAD - PAIN - pulsating pain & BACK - PAIN - joints - gouty \\
\hline HEAD - PAIN - tearing pain & BACK - PAIN - legs - growing pains \\
\hline HEAD - PAIN - forehead - eyes - above & EXTREMITIES - COLDNESS - feet \\
\hline HEAD - PULSATING & EXTREMITIES - COLDNESS - hands \\
\hline HEAD - UNCOVERING - head - agg & EXTREMITIES - CRAMPS - legs - calves \\
\hline EYE - LACRIMATION & EXTREMITIES - PAIN \\
\hline EYE - PAIN & EXTREMITIES - PAIN - rheumatic \\
\hline EYE - PHOTOPHOBIA & EXTREMITIES - PAIN - joints - gouty \\
\hline EAR - PAIN & EXTREMITIES - PAIN - legs - growing pains \\
\hline EAR - PAIN - tearing pain & EXTREMITIES - TREMBLING - hands \\
\hline HEARING - IMPAIRED & EXTREMITIES - WEAKNESS \\
\hline FACE - DISCOLORATION - pale & SLEEP - RESTLESS \\
\hline FACE - PAIN & SLEEP - SLEEPINESS \\
\hline MOUTH - TASTE - bitter & SLEEP - SLEEPLESSNESS \\
\hline TEETH - PAIN & CHILL - CHILLINESS \\
\hline TEETH - PAIN - night & SKIN - SENSITIVINESS \\
\hline THROAT - DRYNESS & GENERALS - NIGHT \\
\hline THROAT - INFLAMMATION & GENERALS - AIR; DRAFT OF - agg \\
\hline THROAT - SC & GENERALS - AIR; IN OPEN - agg \\
\hline STOMACH - APPETITE - increased & GENERALS - COLD - agg \\
\hline STOMACH - APPETITE - ravenous & GENERALS - COLD - agg \\
\hline STOMACH - NAUSEA & GENERALS - COLD - air - agg \\
\hline STOMACH - PAIN & GENERALS - COLD; BECOMING - agg \\
\hline ABDOMEN - DISTENSION & GENERALS - DIABETES MELLITUS \\
\hline ABDOMEN - FLATULENCE & GENERALS - EMACIATION \\
\hline ABDOMEN - PAIN & GENERALS - EXERTION; physical - agg \\
\hline ABDOMEN - PAIN - cramping & GENERALS - HEAT - lack of vital heat \\
\hline ABDOMEN - PAIN - cutting pain & GENERALS - MASTURBATION \\
\hline RECTUM - CONSTIPATION - difficult stool & GENERALS - MOTION - agg \\
\hline RECTUM - DIARRHEA & GENERALS - PAIN - Externally - stitching pain \\
\hline RECTUM - PAIN & GENERALS - PAIN - Externally - tearing pain \\
\hline RECTUM - PAIN - burning & GENERALS - SENSITIVENESS - pain, to \\
\hline STOOL - HARD & GENERALS - SENTIVENESS - externally \\
\hline STOOL - WATERY & GENERALS - TREMBLING - externally \\
\hline
\end{tabular}

Table 4. Symptoms common to homeopathic remedies derived from phosphor

\begin{tabular}{|l|l|}
\hline Total & 94 \\
\hline & 19
\end{tabular}




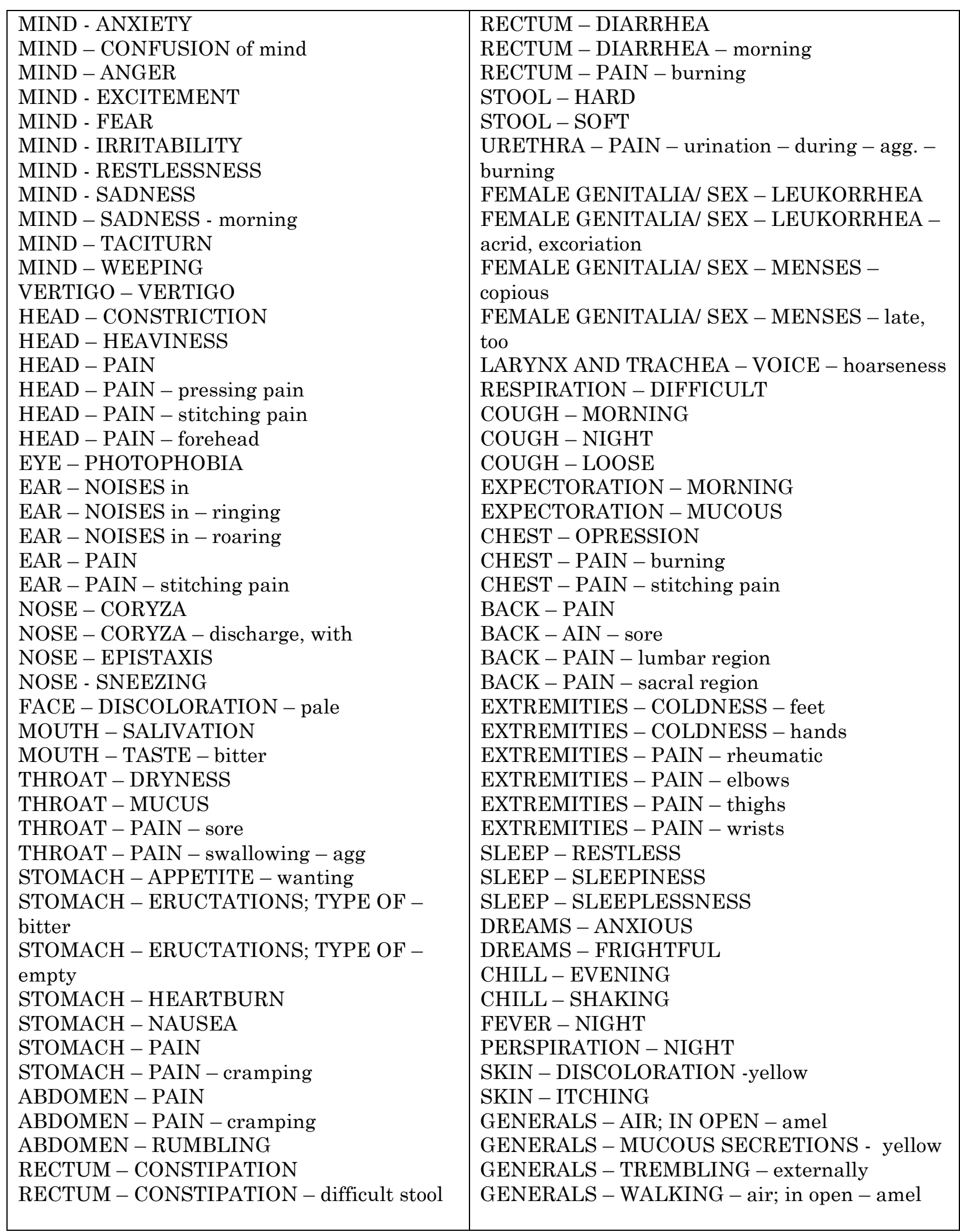

Table 5. Comparison of the symptomatic nuclei of homeopathic remedies derived from carbon, sulfur and phosphor

\begin{tabular}{|l|l|l|}
\hline Carbon & Phosphor & Sulfur \\
\hline Rage & Unhappiness & Rage \\
\hline Moroseness & & \\
\hline
\end{tabular}




\begin{tabular}{|c|c|c|}
\hline Anxiety & & Anxiety; fear \\
\hline \multicolumn{3}{|l|}{$\begin{array}{l}\text { Distraction; difficult } \\
\text { concentration }\end{array}$} \\
\hline $\begin{array}{l}\text { Mental confusion; dullness; } \\
\text { mental prostration }\end{array}$ & Dullness & Mental confusion \\
\hline \multicolumn{3}{|l|}{ Forgetfulness; weak memory } \\
\hline & Excitation & Excitation \\
\hline Irritability & Irritability & Irritability \\
\hline Sadness & Sadness & Sadness; in the morning \\
\hline Indifference & Weeping mood & Weeping mood \\
\hline Laziness & Laziness & \\
\hline Sensitiveness to noises & $\begin{array}{l}\text { Sensitiveness; external } \\
\text { sensitiveness }\end{array}$ & \\
\hline Taciturnity & & Taciturnity \\
\hline \multicolumn{3}{|l|}{ Shyness } \\
\hline Vertigo & Vertigo upon walking & Vertigo \\
\hline \multirow[t]{2}{*}{ Heaviness in the head } & Head congestion; pulsations & Heaviness in head; constriction \\
\hline & Pulsating, tearing headache & Pressing headache; stitching \\
\hline \multirow[t]{2}{*}{ Headache (forehead) } & $\begin{array}{l}\text { Headache (forehead); above the } \\
\text { eyes }\end{array}$ & Headache (frontal; occipital) \\
\hline & Aggravates uncovering the head & \\
\hline Pain in eyes & Tears; pain in eyes; photophobia & Photophobia \\
\hline \multirow[t]{3}{*}{ Noises in ears } & & Noises in ears (bells; roaring) \\
\hline & Earache; tearing & Earache; stitching \\
\hline & Decrease audition & \\
\hline \multirow[t]{2}{*}{ Facial paleness } & Facial paleness & \\
\hline & Pain on the face & \\
\hline \multirow[t]{3}{*}{ Coryza with cough } & & Coryza; discharging; watery \\
\hline & & Epistaxis \\
\hline & & Sneezing \\
\hline \multicolumn{3}{|l|}{ Sensitiveness to odors } \\
\hline & Bitter taste in the mouth & Bitter taste in the mouth \\
\hline Copious saliva & & Salivation \\
\hline \multicolumn{3}{|l|}{ White coating on tongue } \\
\hline & Toothache; night & \\
\hline Dryness of mouth & Dryness in the throat & Dryness of the throat \\
\hline Feeling of a lump in the throat & Inflammation of the throat & Mucus in the throat \\
\hline Soreness in throat & $\begin{array}{l}\text { Feeling of something scratching } \\
\text { the throat }\end{array}$ & $\begin{array}{l}\text { Soreness in throat; aggravation } \\
\text { by swallowing }\end{array}$ \\
\hline \multirow[t]{5}{*}{ Increased appetite } & Increased, ravishing appetite & Lack of appetite \\
\hline & & Belching: empty; bitter \\
\hline & & Heartburn \\
\hline & Nausea & Nausea \\
\hline & Stomachache; crampy & Stomachache; pressing \\
\hline \multirow[t]{4}{*}{ Thirst } & & Thirst \\
\hline & & Mucous vomiting \\
\hline & $\begin{array}{l}\text { Abdominal distension; } \\
\text { flatulence }\end{array}$ & Noises in the abdomen \\
\hline & Bellyache; crampy; cutting & Bellyache; crampy \\
\hline \multirow[t]{3}{*}{ Constipation; difficult stools } & Constipation; difficult stools & Constipation; difficult stools \\
\hline & & Diarrhea; morning \\
\hline & & Burning pain in rectum \\
\hline \multirow[t]{2}{*}{ Hard stools } & Hard stools; watery & Hard or soft stools \\
\hline & $\begin{array}{l}\text { Frequent micturition, especially } \\
\text { in the night; copious urine; } \\
\text { involuntary micturition }\end{array}$ & \\
\hline $\begin{array}{l}\text { Burning pain in urethra, } \\
\text { aggravates on urinating }\end{array}$ & & $\begin{array}{l}\text { Burning pain in urethra; } \\
\text { aggravation by urination }\end{array}$ \\
\hline
\end{tabular}




\begin{tabular}{|c|c|c|}
\hline Amorous dreams & $\begin{array}{l}\text { Increased sexual desire; } \\
\text { pollutions; ailments from } \\
\text { masturbation }\end{array}$ & \\
\hline & & Leucorrhea: acid, corrosive \\
\hline & Painful menstruation & Copious menstruation \\
\hline & Frequent menstruation & Delayed menstruation \\
\hline & Hoarseness & Hoarseness \\
\hline & & Difficult respiration \\
\hline $\begin{array}{l}\text { General aggravation by } \\
\text { coughing }\end{array}$ & & Cough: morning; night \\
\hline \multirow[t]{2}{*}{ Loose cough } & Dry cough; tickling & Dry or loose cough \\
\hline & & Expectoration; morning \\
\hline Yellow expectoration & & Mucous expectoration \\
\hline Oppression of chest & Constriction of chest & Oppression of chest \\
\hline \multicolumn{3}{|l|}{ Palpitations } \\
\hline & Pain in chest & Pain in chest; lumbar; sacrum \\
\hline \multirow{3}{*}{ Backache } & Backache: lumbar; stitching & Soreness in the back \\
\hline & Soreness in the back & Cold hands and feet \\
\hline & Cold hands and feet & Rheumatic pains \\
\hline \multirow[t]{4}{*}{ Heaviness in limbs } & Rheumatic pain & \\
\hline & Growth pain in legs & Pain in elbows; wrists; thighs \\
\hline & Gouty pain in joints & \\
\hline & Cramps in calves & \\
\hline Awakening as if by a fright & Restless sleep & Restless sleep \\
\hline Sleepiness & Sleepiness; sleeplessness & Sleepiness; sleeplessness \\
\hline Anxious, vivid dreams & & Anxious; frightening dreams \\
\hline \multirow{4}{*}{$\begin{array}{l}\text { Chills in general; internal chill; } \\
\text { trembling }\end{array}$} & Chills with cold feeling & Chills in the evening; trembling \\
\hline & & Night fever \\
\hline & & Night perspiration \\
\hline & & Yellow skin \\
\hline Burning itch & Sensitiveness of skin & Itch in the skin \\
\hline Aggravation upon waking up & Aggravation in the night & \\
\hline \multicolumn{3}{|l|}{ Periodicity } \\
\hline $\begin{array}{l}\text { Amelioration in open air; desire } \\
\text { of open air }\end{array}$ & $\begin{array}{l}\text { Aggravation by draft of air; in } \\
\text { open air }\end{array}$ & $\begin{array}{l}\text { Amelioration in open air; } \\
\text { walking in open air }\end{array}$ \\
\hline $\begin{array}{l}\text { Aggravation by cold; lack of } \\
\text { vital heat/// feeling of heat; } \\
\text { flushes }\end{array}$ & $\begin{array}{l}\text { Aggravation by cold; by cold air; } \\
\text { by becoming cold; lack of vital } \\
\text { heat }\end{array}$ & \\
\hline \multicolumn{3}{|l|}{$\begin{array}{l}\text { Feeling of internal and external } \\
\text { heaviness }\end{array}$} \\
\hline & & Yellow mucous discharges \\
\hline \multicolumn{3}{|l|}{ Side: right or left } \\
\hline $\begin{array}{l}\text { Pain: soreness; pinching; } \\
\text { pressing (internal) }\end{array}$ & $\begin{array}{l}\text { Pain: stitching; tearing. } \\
\text { Sensitiveness to pain }\end{array}$ & \\
\hline \multicolumn{3}{|l|}{$\begin{array}{l}\text { Dryness of normally wet parts } \\
\text { of the body }\end{array}$} \\
\hline & $\begin{array}{l}\text { External trembling; trembling } \\
\text { of hands; muscular jerking }\end{array}$ & External trembling \\
\hline $\begin{array}{l}\text { Weakness; weakness upon } \\
\text { walking }\end{array}$ & Weakness; weakness in limbs & Weakness \\
\hline \multicolumn{3}{|l|}{ Lassitude; weariness } \\
\hline $\begin{array}{l}\text { Aggravation: mental effort; } \\
\text { physical effort; motion. }\end{array}$ & $\begin{array}{l}\text { Aggravation: mental effort; } \\
\text { physical effort; motion. Aversion } \\
\text { to mental effort. }\end{array}$ & \\
\hline \multicolumn{3}{|l|}{ Amelioration by lying down } \\
\hline Swelling & Diabetes & \\
\hline Obesity & Emaciation & \\
\hline
\end{tabular}




\section{Symptomatic nucleus obtained from the experimental materia medica versus the "carbonic constitution"}

As a result of studies by Grauvogl, Nebel, Vannier and Bernard, as mentioned above, it was suggested that homeopathic remedy Calcarea carbonica represented the prototype of homeopathic remedies derived from carbon and furthermore, that it corresponded to a hypothetical "carbonic constitution". To verify this notion, we compared the symptomatic nucleus of homeopathic remedies derived from carbon with two sources on this so-called carbonic constitution: Bernard [10,11] and Franco [17]. Results are described in Table 6.

Table 6. Comparison of the symptomatic nucleus of homeopathic remedies derived from carbon and the traditional carbonic constitution

\begin{tabular}{|c|c|c|}
\hline According to Bernard & According to Franco & Carbon nucleus \\
\hline Avoidance of useless efforts & All motions are useful & \\
\hline Moderate appetite & & Increased appetite \\
\hline Physical resistance to disease & $\begin{array}{l}\text { Resistance to fatigue and } \\
\text { disease }\end{array}$ & Lassitude; weakness; weariness \\
\hline Dedicated to studies & Perseverant in work & Lazy; aversion to mental work \\
\hline Distraction & Patience and mental resistance & $\begin{array}{l}\text { Distracted; difficult } \\
\text { concentration }\end{array}$ \\
\hline Lack of understanding & $\begin{array}{l}\text { Clear and exact; cold and } \\
\text { methodic }\end{array}$ & Mental confusion; dullness \\
\hline \multicolumn{3}{|l|}{$\begin{array}{l}\text { Aversion to sports; aversion to } \\
\text { physical effort }\end{array}$} \\
\hline Submissive & $\begin{array}{l}\text { Follows orders, but not } \\
\text { submissively }\end{array}$ & Irritable; morose. Quarrelsome \\
\hline \multicolumn{3}{|l|}{ Lack of courage } \\
\hline Emotional insensitiveness & & $\begin{array}{l}\text { Irritability; rage; morose; } \\
\text { quarrelsome; sadness; } \\
\text { indifference; anxiety }\end{array}$ \\
\hline Stocks trauma in the memory & & Forgetfulness; weak memory \\
\hline Typical carbonic "stocking" trait & & $\begin{array}{l}\text { Forgetfulness; weak memory. } \\
\text { Copious salivation; coryza; loose } \\
\text { cough/// Constipation; swelling }\end{array}$ \\
\hline \multicolumn{3}{|l|}{ Inferiority complex } \\
\hline Values order in work & $\begin{array}{l}\text { Values precision and order in } \\
\text { work }\end{array}$ & $\begin{array}{l}\text { Laziness; aversion to mental } \\
\text { work }\end{array}$ \\
\hline Firmness & $\begin{array}{l}\text { Firm and open in his } \\
\text { commentaries }\end{array}$ & Lassitude \\
\hline Tranquility & & Anxiety \\
\hline \multicolumn{3}{|l|}{ Organization } \\
\hline & Rigidity & Lassitude \\
\hline \multirow{9}{*}{ Fine muscles } & Increased muscular tonus & Lassitude \\
\hline & Regularity & \\
\hline & Repetitive motions & \\
\hline & Motions lack amplitude & \\
\hline & Walk is not elegant & \\
\hline & Beats the heals when walking & \\
\hline & Quick in work & \\
\hline & & $\begin{array}{l}\text { Mental prostration; lassitude; } \\
\text { ameliorated by lying down; } \\
\text { weakness; aggravates walking; } \\
\text { weariness; sleepiness; } \\
\text { aggravation by physical effort; } \\
\text { upon waking up. }\end{array}$ \\
\hline & & Taciturn; timid. \\
\hline
\end{tabular}




\begin{tabular}{|l|l|l|}
\hline & & $\begin{array}{l}\text { Feeling of weight: head; } \\
\text { internal; external; limbs. }\end{array}$ \\
\hline & Sensitiveness to noise; to odors. \\
\hline & Paleness: face; tongue \\
\hline & $\begin{array}{l}\text { Dry mouth; copious salivation; } \\
\text { dryness of normally wet } \\
\text { internal parts; coryza; dry } \\
\text { stools; loose cough. }\end{array}$ \\
\hline & $\begin{array}{l}\text { Palpitations } \\
\text { fleeplessness; wakes up as if }\end{array}$ \\
\hline & $\begin{array}{l}\text { Amelioned } \\
\text { of open air. Aggravation by cold } \\
\text { weather. }\end{array}$ \\
\hline & $\begin{array}{l}\text { General coldness; internal; } \\
\text { worse by cold air; trembling by } \\
\text { coldness; lack of vital heat//l } \\
\text { burning pain on urinating; } \\
\text { burning itch//l feeling of heat; } \\
\text { flushes. }\end{array}$ \\
\hline & & Obesity \\
\hline Fatness & &
\end{tabular}

Simple reading of Table 6 shows, beyond all doubts, that there is no correlation whatsoever between the hypothetical "carbonic constitution" as described by Bernard and Franco and the experimental symptomatic nucleus of homeopathic remedies derived from carbon.

\section{Discussion}

Regarding the identification of symptomatic nuclei of homeopathic remedies derived from carbon, sulfur and phosphor, it must be reminded that one of our aims was to discuss traditional notions on so-called "homeopathic constitutions". For this reason these three classes were selected. However, this kind of study can be - and in view of our results, it is desirable - done with any chemical component of homeopathic remedies. In this way, a "calcium nucleus", a "potassium nucleus", a "sodium nucleus" have already been identified [13] and in the future further nuclei can be also be found, as e.g. an "acetic nucleus", a "nitric nucleus" and perhaps also in botanical and other taxonomies. Nevertheless, verification of the symptomatic nuclei identified in this study can only be performed in actual clinical practice, for which further studies are required.

Regarding so-called "homeopathic constitutions", a flaw can be detected in the very foundation of the full idea. Calcium carbonate is a widely spread substance in nature; it can be found under the most variable forms in all three kingdoms. Homeopathic remedy Calcarea carbonica is prepared through trituration of the middle layer of the shell of oysters, which includes traces of phosphate calcium and other substances. There is no a priori reason to posit this remedy as a prototype for a class of remedies. To obtain experimental evidence to sustain our objection, we cross-checked the traditional view on so-called "carbonic constitution" against the nucleus of experimental effects of homeopathic remedies derived from carbon and clearly found that there is absolutely no positive correlation.

Our results agree with Zissu's observations, warning against the confusion between biotypology and homeopathy, reminding that whereas homeopathy is a medical specialty that approaches the manifestations of disease through the principle of therapeutic similarity, biotypology studies human types in order to make classifications grounded on morphological data and without taking disease into account [12].

Symptomatic nuclei do not constitute easy shortcuts for actual prescription but a methodological tool in the process of homeopathic medical decision-making. Recognizance of one of such nuclei in an actual patient may facilitate both positive and differential diagnosis, through the characteristic signs and symptoms of each individual patient. Moreover, combination of such nuclei, possible in the case of mineral compounds [18], allows one to widen the scope of possible indications to include less known members of a same chemical group, once again, on the grounds of the individual patient's characteristic signs and symptoms. 


\section{Conclusion}

Comparison of symptoms common to homeopathic remedies derived from carbon allowed us to elaborate a symptomatic nucleus of the class that may prove helpful in daily clinical practice. On the other hand, to posit homeopathic remedy Calcarea carbonica as the prototype of this class has no empirical grounds.

The symptomatic nucleus of homeopathic remedies derived from carbon is qualitatively different from both the symptomatic nuclei of homeopathic remedies derived from phosphor and sulfur, and so-called "carbonic constitution". The latter does not seem to have support in experimental homeopathic knowledge.

\section{References}

1. Hahnemann CFS. Doenças crônicas: sua natureza peculiar e sua cura homeopática. $2^{\text {nd }}$ ed. São Paulo (Brazil): Grupo de Estudos Homeopáticos de São Paulo "Benoît Mure”; 1984.

2. Ghatak N. Enfermedades crónicas: su causa y curación. Buenos Aires (Argentina): Albatros; 1991.

3. Masi Elizalde A. Actas del Instituto de Altos Estudios Homeopáticos "James Tyler Kent", vol 8. Buenos Aires; 1994.

4. Sankaran R. About homeopathy [homepage]. Mumbai: Sankaran's Clinic. [cited 2008 May 15] Available from: http://www.sankaransclinic.com/abthmpty.htm.

5. Scholten J. Homeopathy and classifications [homepage]. Utrecht: Jan Scholten. [cited 2008 May 15] Available from: http://www.janscholten.com/files/homeopathy\%20cl assification.pdf.

6. Leeser O. Textbook of Materia Medica. New Delhi (India): B Jain; 2000.
7. Von Grauvogl E. Text book of homeopathy. New York (United States): Boericke \& Tafel; 1870.

8. Schlüssler WH. Una terapia abreviada: guía para el tratamiento bioquímico de las enfermedades. Rio de Janeiro (Brazil): Federação Brasileira de Homeopatia; 1981.

9. Conan Mériadec M. Histórico das diáteses mórbidas às diáteses reacionais. In: Cornillot $\mathrm{P}$, editor. Tratado de Homeopatia. Porto Alegre (Brazil): Artmed; 2005. 96-120.

10. Bernard H. Doctrine homéopathique. Paris (France): Coquemard; 1966.

11. Bernard H. Traité de médecine homéopathique. Paris (France): Coquemard; 1974.

12. Zissu R. Homeopatia e biotipologias. In: Cornillot P, editor. Tratado de Homeopatia. Porto Alegre (Brazil): Artmed; 2005. 121-129.

13. Bungetzianu G, Jurj G. Matéria médica clínica. São Paulo (Brazil): Organon; 2008.

14. Jurj G. A repertory analysis of the high degree symptoms of the main Solanaceae. Rev Rom de Homeopatie. 1999; 4: 45-49.

15. Jurj G. O analiza repertoriala completa a clasei loganiaceelor. Rev Rom de Homeopatie. 2000; 4(12): $16-22$.

16. Schroyens F. Synthesis 9. Namur (Belgium): Archibel; 2006.

17. Franco FJB. Constituição e temperamento: visão unicista e aplicação prática. São Paulo (Brazil): Organon; 2004.

18. Kent JT. New remedies, clinical cases, lesser writings, aphorisms and precepts. Chicago (United States): Erhart and Karl; 1926.

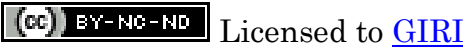

Support: authors declare that this study received no funding Conflict of interest: authors declare there is no conflict of interest Received: 05 Feb 2009; Revised 12 Mar 2009; Published: 31 Mar 2009

Correspondence author: Luciana Costa Lima Thomaz, luc thomaz@hotmail.com

How to cite this article: Thomaz LCL. Symptomatic nuclei of homeopathic remedies: remedies derived from carbon as case-study. Int J High Dilution Res. [online]. 2009 [cited YYYY Month dd]; 8 (26): 15-25. Available from: http://www.feg.unesp.br/ ojs/index.php/ijhdr/article/view/330/381. 